\title{
Konstrusi Hoax Melalui Fitur Media Sosial Dalam Persfektif Cyberculture \\ Hoax Constructions through Social Media Features in a Cyberculture Perspective
}

\author{
Aulian khairani \\ Email: akhairani@unis.ac.id \\ Dosen Program Studi Ilmu Komunikasi Universitas Islam Syekh Yusuf Tangerang
}

\begin{abstract}
ABSTRAK
Fenomena kemunculan hoax di media sosial memang bukanlah hal baru, tetapi penyebarannya yang semakin meluas menjadi persoalan serius bukan hanya pada kasus hukumnya tetapi melihat bagaimana hoax menjadi masalah sosial karena perilaku pengguna media sosial yang telah melegitimasi perilaku manipulatif melalui akun media sosial. Penyebaran informasi bohong bahkan sengaja dilakukan menggunakan fitur-fitur di media sosial untuk tujuan dan kepentingan tertentu sehingga aktifitas menipu dalam ruang public digital kini telah menjadi tren atau budaya baru dikalangan pengguna sosial media. Fokus tulisan ini adalah untuk melihat "bagaimana konstruksi hoax melalui fitur media sosial dalam perspektif cyberculture" yang kemudia dijelaskan secara lebih dalam melalui sub bab bahasan antara lain: konsturksi hoax melalu fitur unggahan foto, konstruksi hoax menggunakan fitur tautan lokasi, konstruksi hoax pada fitur laman bio dan konstruksi hoax melalui fitur status,caption, dan tweet.
\end{abstract}

Kata Kunci : Media sosial, konstruksi, hoax, fitur

\begin{abstract}
Hoaxes phenomenon on social media was nothing new. But the widespread becomes a serious problem not only in legal cases but also how hoaxes become social problems on social media users behavior who have legitimized to manipulative behavior through their own accounts. The spread of fake information is even deliberately used using social media features for certain purposes and interests so that deceptive activities in the digital public roar become a new trend or culture among social media users. The focus of this paper to see "how the construction of hoaxes through social media features in a cyberculture perspective" which is explained through discussion sub-sections including: hoax constituents through photo upload features, hoax construction using location link features, hoax construction on bio page features and hoax construction through status features, captions, and tweets.
\end{abstract}

Keyword: social media, constructions, hoax, feature. 


\section{Pendahuluan}

Dewasa ini, kehadiran media sosial telah menjadi ruang interaksi dimana para penggunanya dapat terhubung sehingga membentuk relasi sosial di dunia virtual, terlebih dengan munculnya berbagai fitur pendukung di dalamnya yang membuat media sosial semakin dapat memenuhi kebutuhan para penggunanya.

Instagram contonya menjadi salah satu media sosial yang memiliki kekuatan karena dilengakapi berbagai fitur pendukung seperti fitur editing, emoji dan lainnya yang diperuntukkan bagi pengguna yang gemar foto dan berswafoto, meskipun di dalamnya terdapat juga fitur untuk menulis teks tetapi sebagian besar penggunanya lebih memanfaatkan instagram sebagai media berbagi gambar/foto. Sebaliknya bagi pengguna yang tertarik menulis dan mengeksplorasi teks twitter, blog dan tumblr dianggap sebagai medium yang lebih tepat, begitupun berbagai media sosial lain dengan segala bentuk keunggulan yang dimiliki.

Kemunculan berbagai media sosial memberikan implikasi pada menjamurnya hoax sebagai sebuah fenomena baru dijagat maya, meskipun telah ada sejak lama kemunculan hoax yang semakin masiv membuat hoax semakin menjadi perhatian serius, berbagi upaya telah dilakukan untuk menangkal penyebaran hoax melalui media sosial mulai dari upaya hukum dengan menjerat pembuat dan penyebarnya menggunakan Undang-undang Informasi Transaksi Elektronik (ITE) dan melalui pendekatan sosial dengan mengkampanyekan pemberantasa hoax namun semua itu tidak membuat hoax berhenti.

Liarnya informasi bohong yang beredar di dunia maya memberikan gambaran mengenai perilaku pengguna media sosial yang minim pemahaman akan pentingnya literasi media untuk memastikan kebenaran informasi yang dibagikan melalui akun media sosial sehingga pengguna sangat rentan memproduksi atau bahkan menyebarkan informasi bohong.

Dalam interaksi di media sosial perilaku kebohongan, manipulasi, bahkan penipuan bukanlah hal baru, Selama ini anonimitas dianggap sebagai sebagai salah satu isu penting yang meresahkan karena dianggap menjadi celah bagi pihak-pihak yang memiliki kepentingan untuk membuat berita atau informasi bohong (hoax) yang disebar luaskan untuk tujuan tertentu.

Selama ini publik terjebak pada pengertian hoax secara umum sebagai berita bohong yang terkait isu atau peristiwa besar saja seperti isu politik, ekonomi, dan bencana alam, sementara jika diterjemahkan dari definisinya hoax dalam Cambridge dictionary kata hoax sendiri berarti tipuan atau lelucon. Beberapa artikel menyebutkan bahwa kegiatan menipu, rencana menipu, trik menipu, disebut dengan hoax. Pada situs hoaxes.org dalam konteks budaya mengarah pada pengertian hoax sebagai aktifitas menipu jika dilihat berdasarkan pengertiannya apapun bentuk perilaku manipulatif dalam ruang publik digital dapat dikategorikan sebagai hoax.

Seharusnya hingga kita tidak hanya terjebak pada pengertian hoax dalam ruang lingkup yang luas karena kenyataanya perilaku menipu telah dilakukan oleh pengguna media sosial, yang secara tidak sadar telah menjadi hal yang biasa atau bahkan telah menjadi kebiasaan dalam persfektif budaya prilaku menipu yang menjadi kebiasaan baru dapat membuat hoax tidak lagi dianggap sebagai sebuah bentuk kejahatan informasi.

Saat ini perilaku manipulatif dalam cyberspace mengalami pergeseran dimana anonimitas bukan lagi satu-satunya penyebab munculnya berbagai informasi palsu di ruang public digital. Kini pemilik akun tidak lagi merahasiakan 
identitasnya menggunakan akun palsu atau fake account untuk mengkonstuk kebohongan informasi karena kehadiran fitur pendukung pada jejaring media sosial juga dimanfaatkan sebagai ruang untuk memanipulasi berbagai informasi mulai dari yang sifatnya personal hingga yang menyangkut kepentingan publik, perilaku seperti ini telah menjadi gaya baru di kalangan warga nett pemilik akun tidak lagu merasa bahwa memanipulasi informasi merupakan sebuah kesalahan justru hal tersebut dianggap sebagai hal yang biasa bahkan digunakan sebagai cara untuk merepresentasikan ciri diri. Mengkonstruk citra diri melalui kebohongan informasi dianggap penting tidak hanya sebgai bentuk eksistensi diri tetapi menjadi medium pertarungan gengsi untuk mengundang simpati.

Konstruksi kebohongan pada fitur media sosial telah menjadi budaya baru di ruang virtual, dalam konteks media studies, kebudayaan bukanlah sesuatu yang historis, melainkan dikonstruksi dan diproduksi. Oleh karena itu, bentuk-bentuk, praktik dan institusi media, akan segera muncul dalam memainkan peran penting dalam produksi kebudayaan. (Fahrurrozi, 2011:76).

Fitur media sosial seperti memiliki peran penting dalam produksi kebudayaan sebagi medium manipulasi informasi yang dikonstruksi melalu, profile, status, lokasi, bio, dll. Berbagai fitur tersebut tidak digunakan sebagaimana seharusnya misalnya banyak yang menjadikan profile sebagai alat pencitraan tidak sedikit mereka yang menggambarkan citra diri melalui gambar profile, seperti memasang gambar dengan menggunakan simbol keagamaan seperti pakaian dan atribut untuk memberikan kesan kepribadian yang religius, ada pula yang yang mengunggah perilaku hedonisme melalui status hanya untuk terlihat mapan, dan masih banyak bentuk prilaku kebohongan lain yang sengaja di konstruksi untuk membentuk citra diri.
Sesungguhnya hoax telah menjadi kebudayaan baru di era digital dimana pengguna dengan sangat terbiasa melakukan kebohongan informasi melalui akun media sosial yang dimiliki dengan menggunakan berbagai fitur yang telah disediakan, meskipun terlihat sederhana perilaku manipulasi memiliki implikasi yang dimana jika terus dikonstruksi akan menjad elemen terpenting dalam proses produksi kebudayaan.

Berdasarkan latar belakang penelitian ini dimana masalah yang diangkat berkaitan dengan produksi dan penyebaran hoax, agar lebih mendalam maka fokus tulisan ini adalah "Konstruksi hoax melalui fitur media sosial dalam persfektif cyberculture" dan diuraikan dalam beberapa sub topik pembahasan yakni : konstruski hoax menggunakan unggahan foto, konstruksi hoax dalam tautan fitur lokasi, konstruksi hoax pada fitur bio, dan konstruksi hoax melalui fitur status, caption atau tweet.

Dengan adanya penilitian ini diharapkan dapat menjadi rujukan dan referensi khususnya dalam bidang ilmu komunkasi untuk meningkatkan pemahaman tentang definisi hoax yang sesungguhnya dan praktik konstruksi budaya hoax di media sosial. Sehingga jika di analisa penulis berpendapat bahwa penelitian sangat layak untuk dilakukan dan dikaji lebih dalam karena sangat penting dan berguna bagi kehidupan di era perkembangan teknologi.

Penelitian ini merupakan jenis penelitian kualitatif, dimana penelitian ini bermaksud untuk memahami segala fenomena tentang apa yang dialami oleh subjek penelitian secara holistik, dan dengan cara mendeskripsikannya dalam bentuk kata-kata dan bahasa, pada suatu konteks khusus yang alamiah dan dengan memanfaatkan berbagai metode ilmiah. (Moleong, 2007:6) 
Paradigma yang digunakan dalam penelitian ini adalah paradigma konstuktivis. Paradigm konstruktivis, memandang ilmu sosial sebagi analisis sistematis terhadap socially meaningful action melalui pengamatan langsung dan terperinci terhadap perilaku sosial yang bersangkutan menciptakan dan memelihara atau mengelola dunia sosial mereka. Paradigm konstruktivis juga merupakan antithesis dari faham yang meletakkan pengamatan dan objektifitas dalam menemukan suatu realitas atau ilmu pengetahuan. (Hidayat, $2003: 3$ )

Dalam penelitian ini peneliti menggunakan data digital dimana peniliti melakukan observasi melalui akun media sosial sehingga data terkait penelitian ini dapat dijadika sebagai subjek analisis untuk selanjutnya dapat dideskripsikan menggunakan kata-kata.

\section{Bahan dan Metode}

\section{Media Sosial}

Dari berbagai perkembangan insdustri media, media sosial merupakan bentuk flatform komunikasi model baru di mana proses interaksi difasilitasi oleh kecanggihan teknologi dalam membangun jaringan relasi sosial di dunia virtual. Sesuai dengan pendapat Zarella (dalam Aditya, R.2015:51) media sosial adalah situs yang menjadi tempat orang-orang berkomunikasi dengan teman-teman mereka, yang mereka kenal di dunia nyata dan dunia maya.

Yang berlain mendefinisikan bahwa media sosial adalah struktur sosial yang dibentuk dari simpul-simpul yang di jalin dengan satu ataulebih tipe relasi spesifik.jejaring sosial atau media sosial bisa di artikan sebagai sarana pemersatu antar individiu satu dengan individu nyang lain sehingga menjadi sebuah sosial yang saling berkaitan (bernteraksi) satu sama lain. ( Ega Dewa: 2014:03)
Media sosial adalah media online yang mendukung interaksi sosial. Sosial media menggunakan teknologi berbaria web yang mengubah komunikasi enjadi dialog interaktif. Beberapa situs media sosial yang popular sekarang ini antaralain : Blog, Twitter, Facebook, Instagram, Path, dan Wikipedia. Definisi lain dari sosial media yang memfokuskan pada eksistensi pengguna yang memfasilitasi mereka dalam beraktivitas maupun berkolaborasi. Karena itu, media sosial dapat dilihat sebagai fasilitator online yang menguatkan hubungan antar pengguna sekaligus sebagai sebuah ikatan sosial.

Menurut Shirky media sosial dan perangkat lunak sosial merupakan alat untuk meningkatkan kemampuan pengguna untuk berbagi (to share), bekerja sama (to cooperate) diantara pengguna dan melakukan tindakan secara kolektif yang semuanya berada diluar kerangka institusional maupun organisasi. Media sosial adalah mengenai menjadi manusia biasa. Manusia biasa yang saling membagi ide, bekerjasama, dan berkolaborasi untuk menciptakan kreasi, berfikir, berdebat, menemukan orang yang bisa menjadi teman baik, menemukan pasangan, dan membangun sebuah komunitas. Intinya, menggunakan media sosial menjadikn kita sebagai diri sendiri.

Beberapa pengertian diatas tentang penggunaan media sosial maka dapat disimpulkan penggunaan medi sosial adalah proses atau kegiatan yang dilakukan seseorang dengan sebuah media yang dapat igunakan untuk berbagi informasi, berbagi ide, berkreasi, berfikir, berdebat, menemukan teman baru dengan sebuah aplikasi online yang dapat digunakan melalui smartphone (telefon genggam). 


\section{Budaya Siber (Cyberculture)}

Budaya siber atau Cyberculture secara sederhana dapat dimaknai sebagai praktik sosial maupun nilai-nilai dari komunikasi dan interaksi antara pengguna yang muncul di ruang siber dari hubungan antar manusia dan teknologi maupun antar manusia dengan perantara teknologi. Budaya itu diproduksi, didistribusi, dan dikonsumsi melalui jaringan internet dan jaringan yang terbentuk di antara pengguna.

Cyberculture menyangkut hubungan antara manusia,computer dan yang kepribadian yang dilakukan di dunia maya. Cyberculture ,merupakan gerakan sosial dan budaya yang terkait erat dengan teknologi informasi dan telekomunikasi. Budaya siber atau cyberculture branjak dari fenomena yang muncul di ruang siber serta media siber budaya pada dasarnya merupakan nilai-nilai yang muncul dari proses interaksi antar individu, dalam konteks ini yaitu pengalaman individu dan atau antar individu dalam menggunakan serta terkait dengan media. Nilai-nilai ini diakui, baik secara langsung maupun tidak, seiring dengan waktu yang dilalui dalam interaksi tersebut. (Nasrullah, 2015:7579)

Dapat dikatakan bahwa segala bentuk interaksi menggunakan perangkat teknologi baik yang bersifat monologis maupun dialogis sebagai ruang publikasi dan konstruksi pesan merupakan bagian dari budaya siber.

Dalam definisi lain cyberculture atau budaya internet adalah budaya yang telah muncul, atau muncul dari penggunaan jaringan computer untuk komunikasi, hiburan dan bisnis. Budaya internet atau cyberculture merupakan studi tentang fenomena sosial yang trkait dengan internet dan bentuk-bentuk lain dari komunikasi jaringan, seperti komunitas online, game multiplayer online, jejaring sosial, pemanfaatan computer dan aplikasi mobile internet.
Mencakup masalah-masalah yang berkaitan dengan identitas, privasi dan pembentukan jaringan. (lev manovich. "new media from borges to HTML" new media reader, ed. Noah Wardrip-fruin \& nick Montfort, (Cambridge, Massachusetts, 2003), h.13-25.

\section{Konstruksi Sosial}

Definisi sosial sebenernya berpandangan bahwa manusia adalah aktor yang kreatif dari realitas sosialnya. Dalam arti manusia aktif melakukan berbagai tindakan dan tidak sepenuhnya ditentukan norma-norma, kebiasaan-kebisaan, nilai-nilai dan sebagainya, yang semuanya tercakup dalam fakta sosial yaitu tindakan yang menggambarkan struktur dan pranata sosial. Manusia dalam banyak hal memiliki kebebasan untuk bertindak di luar batas kontrok struktur dan pranata sosialnya dimana individu berasal. Manusia secara aktif dan kreatif mengembangkandirinya melalui respons-respons terhadap stimulus dalam dunia kognitifnya.

Berger dan Luckman mulai menjelaskan realitas sosial dengan memisahkan pemahaman "kenyataan dan pengetahuan". Realitas diartikan sebagai kualitas yang terdapat di dalam realitasrealitas yang diakui sebagai memiliki keberadaan (being) yang tidak tergantungkepada kehendak kita sendiri. Pengetahuan didefinisikan sebagai kepastian bahwa realitas-realitas itu nyata (real) dan memiliki karakteristik yang spesifik.(Bungin, 2008:14)

\section{Hasil dan Pembahasan}

\section{Konstruksi Hoax Melalui Unggahan Foto}

Fitur foto profile merupakann salah satu fitur dimana pengguna media sosial melakukan perilaku manipulatif atau membuat kebohongan informasi. Perilaku tersebut ditunjukkan dengan cara mencitrakan diri secara berlebihan untuk menunjukkan identitas tertentu, tidak sedikit mengguna media sosial yang ingin terlihat lebih 
religius dengan cara menampilkan foto profile menggunakan symbol-simbol agama, atau banyak pengguna yang ingin terlihat cantik, muda dan terlihat putih kemudian menggunkan aplikasi foto editing agar wajah mereka bisa sesuai dengan yang mereka inginkan.

Banyak yang menganggap ini sebagai suatu kewajaran dimana pengguna memiliki konsep diri yang berbeda namun disadari atau tindakan ini juga menimbulkan kerugian karena banyak pengguna lain yang akhirnya merasa tertipu ketika fakta terungkap. Misalnya saja yang terjadi pada kasus bowo alpenlibe yang dikenal sebagai artis tiktok, tidak sedikit yang akhirnya merasa kecewa setelah berjumpa secara langsung dengannya. Bahkan tidak sedikir pula penggemarnya yang kemudian membuli dan menghinanya. Atau kasus Lucita Luna seorang transgender yang membuat banyak laki-laki tertipu karena foto dirinya yang tampil cantik.

Beberapa kasus di atas hanya menjadi gambaran kecil tentang bagaiaman perilaku megkonstrusi kebohongan telah menjadi sebuah hal yang biasa atau bahakan menjadi kebiasaan baru, meskipun fenomena ini tidak pernah dikaitkan dengan persoalan hukum seperti hal nya kasus hoax yang menyangkut isu besar, perilaku ini merupakan bentuk penipuan yang bisa saja dimanfaatkan untuk kepentingan-kepentingan tertentu sehingga menimbulkan kerugian bagi pihak lain.

Kesadaran pengguna untuk bisa membedakan mana kebohongan dan kenyataan sangatlah penting, meskipun real account dan tidak menggunakan akun palsu tetapi konstruksi informasi bohong yang dilakukan melalui unggahan foto adalah bentuk tindakan yang tidak seharusnya dilakukan apapun motif dan tujuannya karena dengan memproduksi kebohongan seperti ini akan membuat nilai budaya normatif tentang sebuah kebenaran menjadi bias.

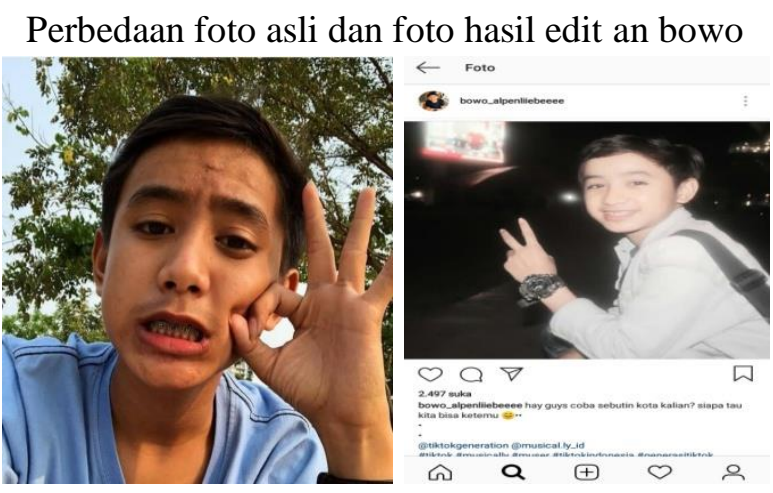

Gambar 1

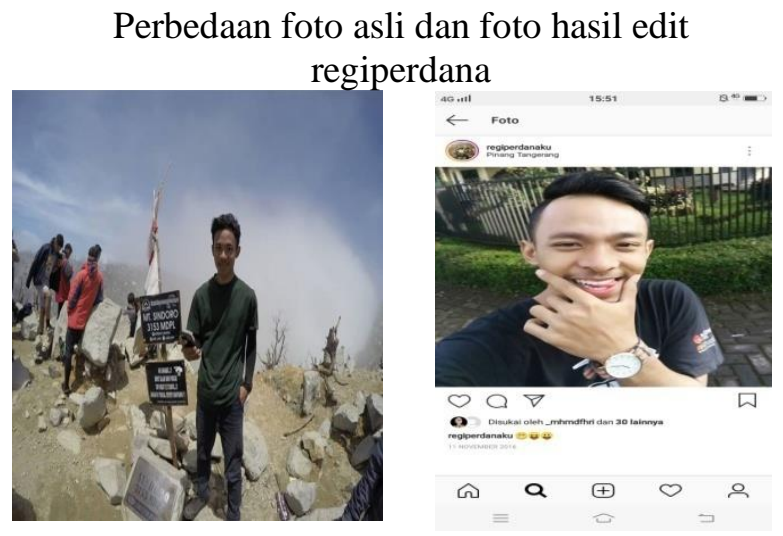

Gambar 2

\section{Konstruksi Hoax Menggunakan Fitur Lokasi}

saat ini fitur lokasi di beberapa media sosial sering kali disalah gunakan oleh pengguna, fitur lokasi yang seharusnya digunakan untuk memperjelas informasi justru dimanfaatkan sebagai medium membuat informasi bohong (hoax) dengan kata lain pengguna media sosial tidak menggunakan fitur lokasi sebagaimana fungsinya. Pengguna menjadikan lokasi sebagai sarana eksistensi diri, penautan lokasi dianggap mampu memberikan kesan terhadap citra diri pemilik akun. Bentuk manipulasi dapat terlihat jelas ketika pemilik akun memposting foto dengan menautkan lokasi yang berbeda dari lokasi yang terdapat di foto. 
Meskipun dianggap hanya sebuah lelucon seperti hal nya definisi hoax yang dikemukakan diawal kemunculannya penautan lokasi yang bukan sebenernya yang seharusnya info lokasi tersebut menunjukkan tempat dimana foto tersebut diambil, hal ini semakin menegaskan bahwa budaya menyebarkan kebohongan seperti ini sengaja diproduksi untuk menarik perhatian pengguna lain.

Sebagian pengguna beranggapan bahwa perilaku kebohongan semacam ini bukan merupakan sebuah bentuk kejahatan, atau mungkin karena telah menjadi sebuah kebiasaan baru atau karena ketidak tahuan pemilik akun dan pengguna media sosial tentang bagaiamana seharusnya memanfaatkan fitur di media sosial secara benar atau karena pengguna media sosial belum mengetahui dan memahami apa yang disebut dengan hoax sehingga mereka begitu mudah menyebarkan kebohongan melalui akun media sosial mereka.

Menyebarkan kebohongan semacam ini juga memungkinkan akan ada pihak yang akan dirugikan meskipun tidak seperti kasus hoax menyangkut isu atau peristiwa besar. Setidaknya banyaknya tautan lokasi palsu di media sosial merupakan bentuk budaya baru yang sengaja dikonstruk untuk berbagai motif tertentu.

\section{Lokasi ditautkan: Berlin, Germany}

Lokasi asli: Jakarta

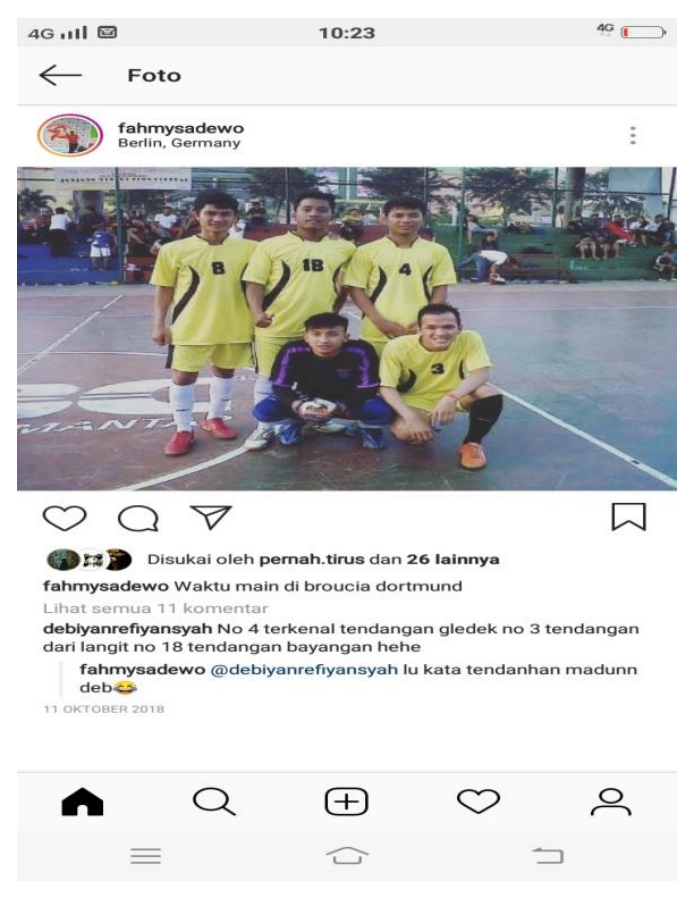

Gambar 3

Lokasi ditautkan: Toilet

Lokasi asli: Lapangan depan kampus

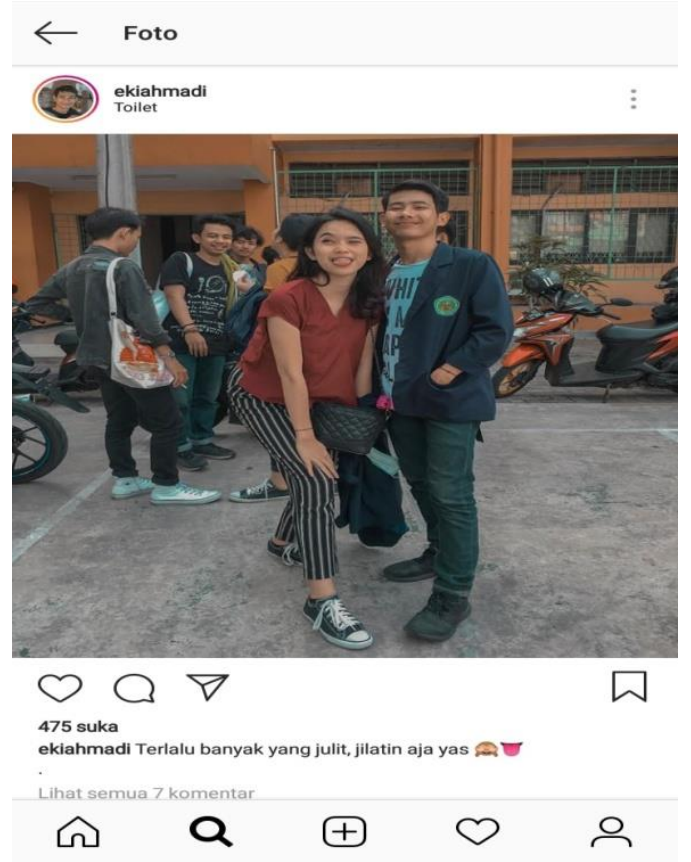

Gambar 4 


\section{Konstruksi Hoax Menggunakan Fitur Bio}

Laman bio pada media sosial merupakan fitur yang disediakan untuk mendiskripsikan identitas memilik akun, jika semua pengguna mesosial menggunakan identitas dengan benar seharusnya fitur bio dapat meminimalisir kejahatan di media sosial. Tidak hanya persoalan nama dan foto yang dipaskuan atau lebih populer dengan sebutan anonim dan psyedonim keterangan lain pada bio juga menjadi ruang konstruksi hoax yang sering disalah gunakan.

Perilaku manipulatif pada fitur bio sering kali dianggap sebuah lelucon yang ketika dipalsukan bukanlah sebuah masalah, sesungguhnya keterangan bio pada media sosial dapat dimanfaatkan untuk menjelaskan latar belakang identitas pemilik akun sehingga dapat membantu pemilik akun lain dalm hal kenyamanan berinteraksi. Seperti halnya keterangan status, pendidikan dan lokasi tempat tingga pada bio jika dipublikasi dengan data yang benar pengguna lain dapat membatasi interaksi berdasarkan latar belakang kesamaan identitas misalanya kesamaan pendidikan, usia, status atau profesi. Selain itu beberpa pengguna terlihat memanipulasi fitur bio untuk kepentinggan popularitas atau sebagai media untuk membangun personal branding.
Tampilan Fitur Bio Yang dimanipulasi
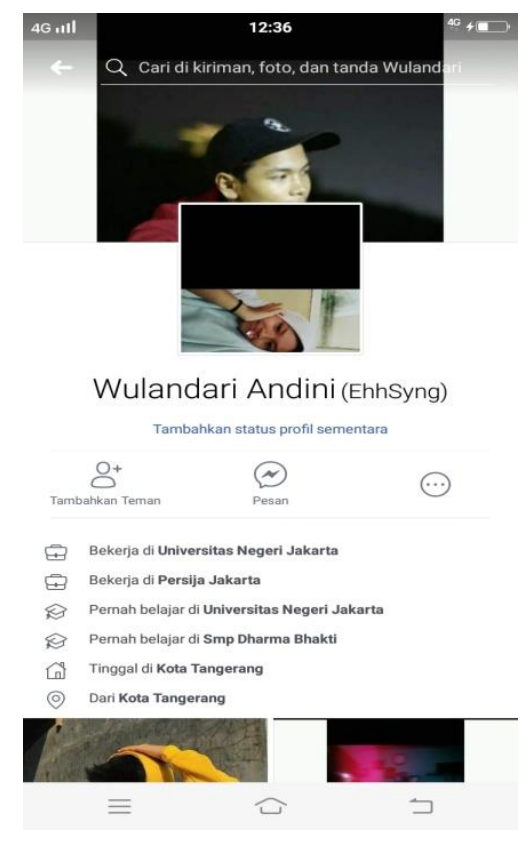

Gambar 5

Tampilan Fitur Bio Yang dimanipulasi
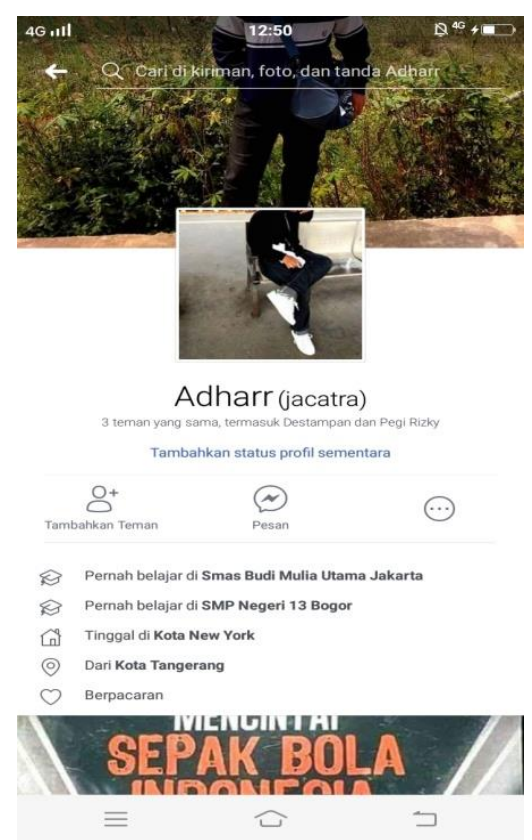

Gambar 6 
Tampilan Fitur Bio Yang dimanipulasi

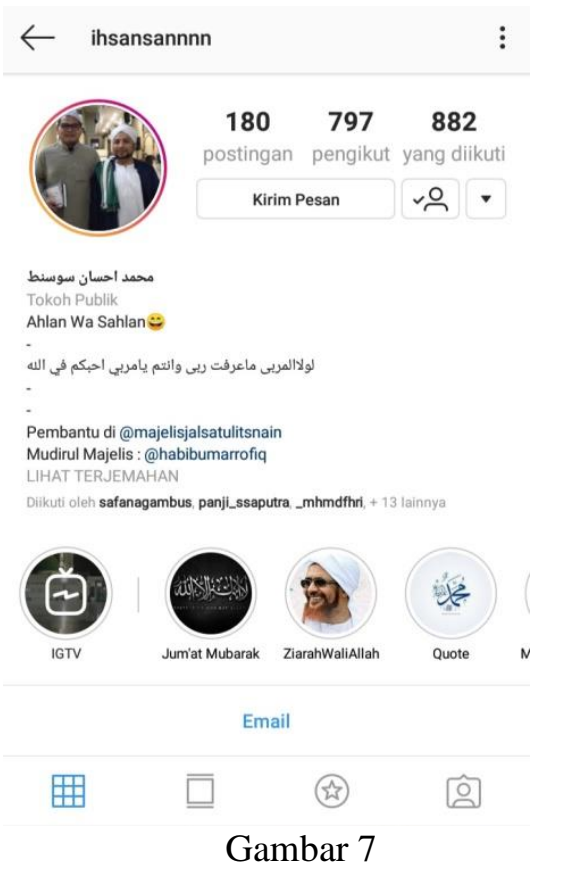

Pada gambar 5 pemilik akun merupakan siswi SMP tetapi di fitur bio media sosialnya pemilik akun menuliskan keterangan sebagai mahasiswi, dan bekerja di salah satu Perguruan Tinggi Negeri, pada gambar 6 pemilik akun memanipulasi identitas pendidikan dan tempat tinggalnya, sekolah yang ditautkan pada laman bio bukan merupakan sekolah tempat dimana pemilik akun menempuh pendidikan atau dengan kata lain pemilik akun mencantumkan nama sekolah palsu, begitupun tempat tinggalnya pada deskripsi bio dituliskan bahwa pemilik tinggal di kota New York salah satu kota besar di Amerika serikat, padahal saat ini pemilik akun bertempat tinggal di tangerang bahkan yang bersangkutan tidak pernah sekalipun mengunjungi kota New York.

Pada gambar 7 telihat akun media sosial yang digunakan berbeda ini menunjukkan bahwa perilaku manipulatif terjadi disemua platform media sosial, pada akun instagram di atas dituliskan bahwa pemilik akun merupakan tokoh publik. Padahal pemilik akun hanyalah seorang mahasiswa dan tidak memiliki rekam jejak sebagai tokoh publik. Dan tidak sedikit pengguna yang menuliskan deskripsi sebagai tokoh publik padahal hanya orang biasa. Atau menuliskan keterangan lain yang bukan merupakan profesinya misalnya seniman, musisi dan lainnya.

\section{Konstruksi Hoax melalui Fitur Status, Caption atau Tweet}

Dari sekian banyak hoax yang diproduksi menggunakan fitur media sosial konstruksi hoax melalui status, caption, atau tweet yang paling banyak mendapat perhatian. Hal ini terjadi karena penyebaran hoax yang berkaitan dengan peristiwa atau isu besar banyak disebarluaskan melalui fitur status di media sosial. Setiap bentuk media sosial menyediakan sarana bagi pengguna untuk menulis teks kemudia dipublikasi dan bagikan kepada khalayak banyak, sehingga hoax yang dibuat pada fitur status lebih mudah mempengaruhi dan menjangkau pengguna lain.

Status, caption atau tweet menjadi medium yang dimanfaatkan untuk menyebarkan pesan atau informasi bohong berkaitan dengan peristiwa atau isu tertentu yang dibuat secara sengaja untuk kepentingan tertentu. Status, caption atau tweet bukan lagi menjadi fitur privasi dimana pengguna bisa menulis hal-hal yang berkaitan dengan apa yang ingin dibagi.

Kini fitur status, caption, atau tweet telah menjadi ruang publik dimana teks yang ditulis adalah sesuatu yang ditunjukkan untuk publik. Oleh karena itu fitur ini sering kali digunakan untuk kepentingan politis dan ekonomis, seperti halnya kasus penyebaran berita bohong yang paling fenomenal seorang aktifis perempuan yang merupakan tim pemenangan salah satu pasangan calon mengaku dianiaya kejadian ini kemudian secara spontan memicu reaksi 
sejumlah politisi yang secara bersamaan mengunggah informasi tersebut melalui status, caption, atau tweet di media sosial mereka yang kemudian terbukti hoax membuat gaduh, resah atau bahkan dianggap merugikan pihak tertentu. Banyak kasus lain seperti hoax gempa susulan, surat suara tercoblos yang akhirnya berhasil diungkap.

Kasus konstruksi hoax melalui status adalah yang paling memiliki implikasi terhadap sanksi hukum. Tidak sedikit mereka yang membuat atau menyebarkan informasi bohong melalui status, caption atau tweet yang harus menjalani proses hukum karna dianggap membuat keresahan dan kegaduhan.

\section{Hoax Surat Suara Tercoblos}

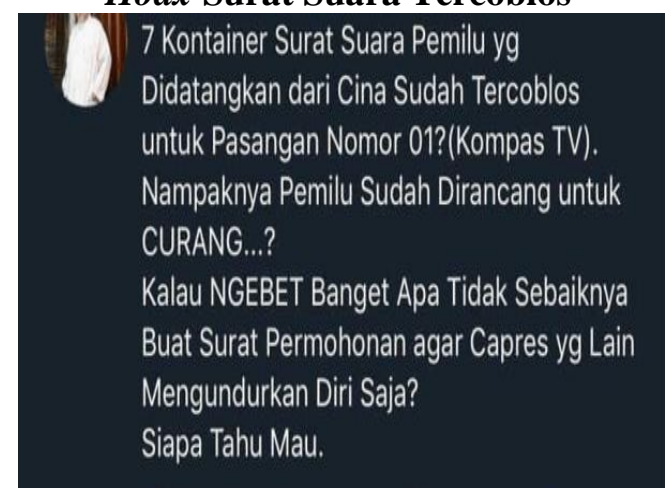

Gambar 8

\section{Hoax gempa susulan}

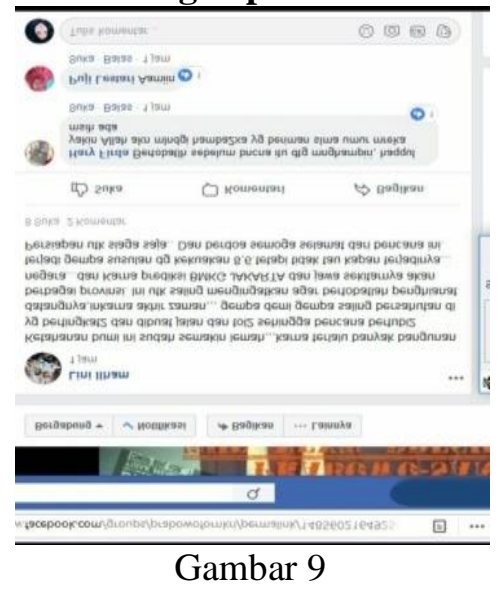

\section{Hoax Penganiayaan Ratna}

7 Kontainer Surat Suara Pemilu yg

Didatangkan dari Cina Sudah Tercoblos

untuk Pasangan Nomor 01? (Kompas TV).

Nampaknya Pemilu Sudah Dirancang untuk

CURANG...?

Kalau NGEBET Banget Apa Tidak Sebaiknya

Buat Surat Permohonan agar Capres yg Lain

Mengundurkan Diri Saja?

Siapa Tahu Mau.

\section{Penutup}

Ada berbagai cara yang telah dilakukan untuk menghentikan pembuatan dan penyebaran hoax di media sosial salah satunya melalui sanksi hukum, namun ada upaya yang lebih penting dilakukan kepada pengguna untuk mencegah pembuatan dan penyebaran hoax dengan cara memberikan pemahaman tentang defisini hoax secara pengguna secara sadar menghentikan perilaku kebohongan di akun media sosial, karena dengan membiarkan perilaku tersebut akan menjadi kebiasaan yang akan manjadi kebudayaan baru di ruang public virtual.

Pengguna harus menyadari bahwa memanipulasi informasi di media sosial merupakan bentuk hoax yang bisa saja menimbulkan kerugian pihak lain. Selain itu, dampak dari kebohongan yang dilakukan menggunakan akun media sosial bukan tidak mungkin dapat mengonstuksi hoax yang lebih besar karena perilaku tersebut dianggap sebagai hal yang biasa. 
Pemberantasan hoax harus dimulai dari pemahaman dan komitmen pengguna untuk dapat memanfaatkan media sosial sebagaimana mestinya agar interaksi yang terjalin di ruang publik digital dapat memberikan dampak positif bagi pemilik akun dan pengguna media sosial lainnya

\section{Daftar Pustaka}

Aditya, R. (2015). Pengaruh media sosial Instagram terhadap minat fotografi pada komunitas fotografi pekanbaru. Jurnal FISIP, 2, hal.51.

Bungin, M. Burhan. 2008. Konstruksi Sosial Media Massa. Jakarta: Kencana. Hal.14

Dedy N. Hidayat. (2003). Paradigma dan Metodologi Penelitian Sosial Empirik Klasik, Jakarta : Departemen Ilmu Komunikasi FISIP Universitas Indonesia. Hal 3.

Fahrurozi, Moch. (2011). Islam Digital Ekspresi Islam di Internet. Bandung: Sajjad Publishing. Hal 76.

Nasrullah, Rulli. (2015). Media Sosial Persfektif Komunikasi, Budaya, dan Sosioteknologi. Bandung: Simbiosa Rekatama Media. Hal 7579.

Moleong, Lexy J. (2007). Metode Penelitian Kualitatif, Bandung: PT Remaja Rosdakarya. Hal.6

Putra, Ega Dewa. (2014). "Menguak Jejaring Sosial". Serpong : Putra. Hal 51. 